\title{
INDONESIAN LAW REFORM AND THE PROMOTION OF JUSTICE: AN ANALYSIS OF LAW REFORM IN THE POST- SOEHARTO PERIOD
}

\author{
Hannah McGuire \\ Law Schools, Faculty of Laws, Humanities and Arts \\ University of Wollongong \\ Email: hjm919@uowmail.edu.au
}

\begin{abstract}
This paper focused on law reform in Indonesia post-Soeharto period. It analyses whether the promotion of justice has been conducted. It aims to analyse whether the law reform during the reign of B.J. Habibie impeded on the promotion of justice. This paper takes the position that the promotion of justice was absent during Soeharto's presidency, and through an analysis of five law reforms introduced after his downfall No. 2 of 1999 on Political Parties, No. 3 of 1999 on General Elections, No. 28 of 1999 on Corruption, Collusion and Nepotism, No. 31 of 1999 on the Eradication of Corruption and No. 39 of 1999 on Human Rights. It is argued that that the laws introduced during the Post-Soeharto era did not see to the complete promotion of justice.
\end{abstract}

Keywords: justice, promotion of justice, law reform, Indonesia, post-Soeharto

\section{INTRODUCTION}

The Encyclopaedic Australian Legal Dictionary defines law reform as the modification of law, through the elimination of defects, the simplification of current law or the adoption new enforcement methods, in order to ensure the promotion of justice. $^{1}$ The concept of justice is a considerably disputed term, and therefore to determine the elements of which it is comprised, one must look to

\footnotetext{
LexisNexis, Encyclopaedic Australian Legal Dictionary (at 6 February 2015) 'Law Reform'.
}

the literature of jurisprudence. Focusing on the law reform in Indonesia during the Post-Soeharto period, 1998-1999, this paper aims to analyse whether the law reform during the reign of B.J. Habibie impeded on the promotion of justice. This paper takes the position that the promotion of justice was absent during Soeharto's presidency, and through an analysis of five law reforms introduced after his downfall - No. 2 of 1999 on Political Parties, No. 3 of 1999 on General Elections, No. 28 of 1999 on Corruption, Collusion and Nepotism, 
No. 31 of 1999 on the Eradication of Corruption and No. 39 of 1999 on Human Rights, ${ }^{2}$ it will be concluded that the laws introduced during the PostSoeharto era did not see to the complete promotion of justice.

\section{METHODOLOGY}

This paper uses juridicalnormative method, including reviewing and analysing justice issue in postSoeharto Era. The approach used in this paper is conceptual and statute approach. The concept of justice in Indonesia will be analysed both during Soeharto Era and post-Soeharto Era. Legal analyses conducted towards

${ }^{2}$ Undang-Undang Republik Indonesia Nomor 2 Tahun 1999 Tentang Perubahan Atas [Laws of the Republic Indonesia Number 2 of 1999 On Political Parties] (Indonesia) [author's trans]; Undang-Undang Republik Indonesia Nomor 3 Tahun 1999 Tentang Pemilihan Umum [Laws of the Republic Indonesia Number 3 of 1999 On General Election] (Indonesia) [author's trans]; Undang-Undang Republik Indonesia Nomor 28 Tahun 1999 Tentang Penyelenggara Negara Yang Bersih Dan Korupsi, Kolusi Dan Nepotisme [Laws of the Republic Indonesia Number 28 of 1999 On Organizers of the Clean and Free From Corruption, Collusion and Nepotism] (Indonesia) [author's trans]; Undang-Undang Republik Indonesia Nomor 31 Tahun 1999 Tentang Pemberantas San Tindak Pidana Korupsi [Laws of the Republic Indonesia Number 31 of 1999 On Eradication of Corruption] (Indonesia) [author's trans]; Undang-Undang Republik Indonesia Nomor 39 Tahun 1999 Tentang Hak Asasi Manusia [Laws of the Republic Indonesia Number 39 of 1999 On Human Rights] (Indonesia) [author’s trans]. answering the question of whether a complete promotion of justice has been achieved during the post-Soeharto Era.

\section{III.RESULT AND DISCUSSION \\ LAW REFORM AND JUSTICE}

Law reform plays a fundamental role in the facilitation of progressive change within societies, as it is the process in which the law evolves to achieve unanimity between the values and needs of society. Justice Michael Kirby states:

[Law reform] is part of the mechanism of modernizing and up-dating our legal system to make it more just and more relevant to the problems of today. [The law must be reviewed] in a systematic way, modernizing it where necessary and changing it where the change will lead to improvement. Law reform is not change for its own sake. It is change for the better. ${ }^{3}$

If law reform is the alteration of legislation to ensure the achievement of justice, ${ }^{4}$ it must be determined what is required to ensure that the reform is

${ }^{3}$ Chief Justice Michael Kirby, 'Law Reform and Class Actions' (Speech delivered at the Australian Society of Senior Executives, Sydney, 31 July 1979) < http://www.michaelkirby.com.au/images/stories /speeches/1970s/vol4/1979/112-

Aus_Society_of_Senior_Executives__Law_Reform_and_Class_Actions.pdf $>$.

${ }^{4}$ LexisNexis, Above $n 1$. 
'just', or alternatively, what makes it 'unjust'. As the requirements to achieve justice may vary from one individual to another, as L.B Curzon explains in his book The Dictionary of Law, one must reconcile the various definitions of the literature of jurisprudence to determine the definition of such a difficult legal concept. $^{5}$

Alf Ross states, "justice is the correct application of a law, as opposed to arbitrariness”, 6 whilst Edgar Bodenheimer believes, “justice demands that freedom, equality and other basic rights be accorded". ${ }^{7}$ Brian Barry, a strong believer of democracy, suggests justice may only be evident when society is ruled under "a political system in which parties represent the distinctive interests and aspirations of different groups”. ${ }^{8}$ Conversely, John Stuart Mill takes a more structured approach, suggesting that the concept of justice has two elements:

[A] rule of conduct and sentiment which sanctions the rule. The first must be

\footnotetext{
${ }^{5}$ Leslie Basil Curzon, The Dictionary of Law (Trans-Atlantic Publications, $5^{\text {th }}$ ed, 1998) 37.

${ }^{6}$ Alf Ross, On Law and Justice (The Lawbook Exchange, first published 1959, 2012 ed) 173.

${ }^{7}$ Edgar Bodenheimer, Jurisprudence: The Philosophy and Method of the Law (Harvard University Press, 2nd ed, 1967) 4.

8 Brian Barry, Theories of Justice (University of California Press, 1991) 347.
}

supposed common to all mankind and intended for their good; the sentiment is a desire that punishment may be suffered by those who infringe the rule. ${ }^{9}$

Alternatively, Aristotle believes justice will always be achieved by the laws of society at the time, as they are superior and are the standard to assess what is 'right'. ${ }^{10}$ For Plato, a sufficient definition of justice identifies its essence through the various shared features of a diverse range of definitions. ${ }^{11}$ Just as Plato suggests, ${ }^{12}$ it may be determined what the key elements of justice are from an amalgamation of these explanations.

These six prominent legal philosophers, from varying periods of time and schools of thought, arguably derive the elements necessary for law reform to achieve complete and utter ‘justice’: (1) equality before the law, (2) enforce the ideals of democracy, and (3) an absence of arbitrariness. Equality before the law is the principle in which all persons of a state are subject to the same treatment by the law, in

9 John Stuart Mill, Utilitarianism (Hackett Publishing Company, $2^{\text {nd }}$ ed, 2002) 61.

10 Aristotle, Politics (University of Chicago Press, $\left.2^{\text {nd }} e d, 2013\right) 25$.

11 Plato, Laws (Dover Publications, 2006) 32 .

12 Ibid. 
application and substance. ${ }^{13}$ It ensures that everyone is entitled to "a fair and public hearing by a competent, independent and impartial” judge, ${ }^{14}$ promoting the notion of due process. The second element, democracy, is the concept where every citizen has the opportunity to participate directly in the determination of the government, evident through a legislative assembly that represents the whole people. ${ }^{15}$ Finally, an arbitrary action or decision is one not based on reason, but on personal discretion or will without concern for the standards. ${ }^{16}$ It is suggested that law reform that contradicts one of these elements will hinder the promotion of justice.

Through this examination of theoretical literature, it can be submitted that the achievement of justice is a useful guide to evaluate the merits of law reform. Whilst it may be suggested that as the elements which justice are comprised of are disputed, and "the fact

13 David Byrne, 'Equality Before the Law’ (1970) 2 Dublin University Law Review 40, 41.

${ }^{14}$ International Covenant on Civil and Political Rights, opened for signature 16 December 1966, 999 UNTS 171 (entered into force 23 March 1976) art 14.

15 LexisNexis, Above n 1, 'Democracy'.

${ }^{16}$ Peter Butt and David Hamer (eds), LexisNexis Concise Australian Legal Dictionary (LexisNexis, $4^{\text {th }}$ ed, 2011) 34. that those norms employed as standards of justice may vary from one individual to another", ${ }^{17}$ this does not ground the idea that the principles embodied by the term should be discarded simply because they are challenged. Key legal concepts that are widely debated, such as good governance and the rule of law, 18 constitutionalism, 19 and accountability, ${ }^{20}$ form the basis of analysis in numerous esteemed authors' works. Therefore the elements that constitute justice, as derived above, provide a foundation in which Habibie's law reforms in the period of 1998-1999 may be analysed.

\section{THE NEED FOR LAW REFORM IN 1998-1999 INDONESIAN SOCIETY}

In order to determine whether various legislative enactments under President B.J Habibie’s rulership

${ }^{17}$ Achmad Ali, 'Law and Development in Changing Indonesia’ (Research Report, No 8, Institute of Developing Economies, 12 March 2001) 104.

18 See Nadirsyah Hosen, Reform of Indonesian Law in the Post-Soeharto era (19981999) (PhD Thesis, The University of Wollongong, 2004).

${ }^{19}$ See Mattias Kumm, 'The Legitimacy of International Law: A Constitutionalist Framework of Analysis' (2004) 15(5) European Journal of International Law 907, 908.

20 See Jane Stromseth, 'Pursuing Accountability for Atrocities After Conflict: What Impact on Building the Rule of Law?' (2007) 38 Georgetown Journal of International Law 251. 
promote the ideals of justice, one must examine the laws during his predecessor Soeharto’s reign. Soeharto’s presidency was characterized by inequitable political policies, rampant corruption in judicial and investigative processes and lack of due process leading to human rights abuses.

Soeharto's New Order regime mandated a 'closed' political system, allowing the formation of three political parties - Golongan Karya (Golkar), Partai Persatuan Pembangunan (PPP) and Partai Demokrasi Indonesia (PDI). ${ }^{21}$ Elections were carried out unethically, with voting occurring whilst in the workplace and the absence of an independent supervising committee. ${ }^{22}$ Under these conditions, the Soeharto’s Golkar party, won the 1971, 1977, 1982, 1987, 1992 and 1997 elections with the supposed support of over $60 \%$ of the voters. ${ }^{23}$ Further, Indonesian politics during the rule of Soeharto was marked with a lack of accountability and transparency, the result of rampant corruption throughout

${ }^{21}$ Hans Antlöv and Sven Cederroth, Elections in Indonesia: The New Order and Beyond (RoutledgeCurzon, 2004) 138.

22 Ibid.

23 Leo Suryadinata, 'A Year of Upheaval and Uncertainty: The Fall of Soeharto and Rise of Habibie' [1999] Southeast Asian Affairs 111, 113. the system. Throughout Soeharto’s rule, there were numerous complaints to authorities regarding the "rapacious rentier business practices” of his immediate family members and business associates, ${ }^{24}$ however due to a lack of impartial investigative authorities during this time these claims did not lead to prosecution. Soeharto ensured that the profits of corruption were spread throughout the government and legislature, so all bureaucrats, judges, police and the Attorney General had some stake. Through this dispensation of 'favours', his term in office continued to extend. ${ }^{25}$

As a result of prejudiced political policies and rampant corruption, the general population took a stand against his dictatorship, with student and mass protests. However, with a corrupt military and a lack of due process, many protestors were jailed, tortured and killed. With the outcry by so many for Soeharto to resign from his Presidency, he did so with much hesitation in May 1999. On the following day, B.J Habibie was

\footnotetext{
${ }^{24}$ Andrew MacIntyre, 'Institutions and the Political Economy of Corruption in Developing Countries' (Paper presented at Workshop on Corruption, Stanford University, 31 February 2003) 4

${ }^{25}$ Ibid.
} 
appointed to the President of Indonesia with the expectation of reforming Indonesia into a fair and democratic nation which promotes justice for all.

\section{POLITICAL LAW REFORM}

Brian Barry, in his work Theories of Justice, acknowledges that a legal system that adopts the ideals of democracy will increase the likelihood of the promotion of justice. ${ }^{26} \mathrm{~A}$ prerequisite of democracy is conducting uncorrupt general elections, in which the population is able to freely vote and political parties can campaign without fear of government coercion. President Habibie, in his strive to ensure the promotion of justice, introduced two legislative reforms, No 2 of 1999 on Political Parties and No 3 of 1999 on General Elections, ${ }^{27}$ to ensure Indonesia held its first "free and fair election" in 1999. ${ }^{28}$ Whilst the legislation was beneficial from a number of

\footnotetext{
${ }^{26}$ Barry, above $n 7$.

${ }^{27}$ Undang-Undang Republik Indonesia Nomor 2 Tahun 1999 Tentang Perubahan Atas [Laws of the Republic Indonesia Number 2 of 1999 On Political Parties] (Indonesia) [author's trans]; Undang-Undang Republik Indonesia Nomor 3 Tahun 1999 Tentang Pemilihan Umum [Laws of the Republic Indonesia Number 3 of 1999 On General Election] (Indonesia).

28 Greg Baron, ' Democracy in Indonesia' The Monthly (online) July 2009 <https:/www.themonthly.com.au/issue/2009/jul y/1360559640/greg-barton/comment>.
}

perspectives, such as high voter participation, low violence level and a peaceful transfer of power, the reforms were also flawed with serious shortcomings. ${ }^{29}$ The aim of these reforms was to restore the imbalances in the promotion of justice through Soeharto's questionable politics. However, it can be submitted that these reform hindered the promotion of justice due to the vagueness of the laws resulting in arbitrary decision-making, a lack of appeal process offending the principle of equality before the law, and the appointment of members of the legislature contradicting the principles of democracy.

Law No. 2 of 1999 and Law No. 3 of 1999 do not result in the total promotion of justice as, due to the reforms' lack of clarity, significant gaps are left in the law resulting in arbitrary decision-making. In order to remedy this issue and create comprehensive applicable laws, the National Election Committee (KPU) was authorised to use its discretion to clarify the legislation, ${ }^{30}$

${ }^{29}$ Ben Hillman, 'Electoral Governance and Democratic Consolidation in Indonesia' (2011) 39(3) The Indonesian Quarterly 301, 302.

${ }^{30}$ Undang-Undang Republik Indonesia Nomor 3 Tahun 1999 Tentang Pemilihan Umum [Laws of the Republic Indonesia Number 3 of 
resulting in the issuance of more than two hundred regulations and a problematic hybrid system. ${ }^{31}$ The difficulties created through this unrestricted discretion can be clearly seen when observing the Election Commission Formation Preparation Committee (Election Commission), a body formed by the KPU to determine which of the political parties met the legal requirements to run in the 1999 General Election. Article 39(5) states that the "registration of political parties to participate in the General Election, is regulated by the decisions of the [Election] Commission”. 32 The contradiction of the ideals of Pancasila was the only guidance to determine which of the 148 newly formed political parties met the 'legal' requirements to participate in the General Election, ${ }^{33}$

1999 On General Election] (Indonesia) art 16(84) [author's trans].

31 Nadirsyah Hosen, 'Indonesian Political Laws in Habibie Era: Between Political Struggle and Law Reform' (2003) 72 Nordic Journal of International Law 483, 515.

${ }^{32}$ Undang-Undang Republik Indonesia Nomor 3 Tahun 1999 Tentang Pemilihan Umum [Laws of the Republic Indonesia Number 3 of 1999 On General Election] (Indonesia) art 39(5) [author's trans].

${ }^{33}$ Loren Ryters, 'Permuda Pancasila: The Last Loyalist Free Man of Suharto's Order?' (1998) 66 Indonesia 44, 44, provides that Pancasila is the official philosophical foundation of the Indonesian nation, comprising of five broad requirements - (1) belief in the one and only god, (2) just and civilized humanity, (3) the unity of Indonesia, (4) article 2 providing that the "characteristics, aspirations and Political Party program [shall] not conflict with Pancasila”. 34 The determination of how to interpret and apply this concept was left to the Committee's discretion. With no mechanism to ensure the correct and equal application of this criteria, the KPU and Election Commission formed a 'super body', ${ }^{35}$ with unlimited discretion and able to act according to their own arbitrary will. As Law No. 2 of 1999 and Law No. 3 of 1999 permit arbitrariness in decision-making, it cannot fulfill the criteria for the complete promotion of justice.

Further, Law No. 2 of 1999 does not uphold the promotion of justice in its entirety as it offends the principle of equality before the law due to its lack of appeal process. Article 12 states that "the supervision of the provisions contained in this legislation is done by the Supreme Court of the Republic of

democracy guided by the inner wisdom in the unanimity arising out of deliberations amongst representatives, and (4) social justice for all of the people of Indonesia.

${ }^{34}$ Undang-Undang Republik Indonesia Nomor 2 Tahun 1999 Tentang Perubahan Atas [Laws of the Republic Indonesia Number 2 of 1999 On Political Parties] (Indonesia) art 2(2) [author's trans].

${ }^{35}$ Hosen, Reform of Indonesian Law in the Post-Soeharto era (1998-1999), above n 17, 198. 
Indonesia”, ${ }^{36}$ and the court has the ability to "dissolve or suspend" a political party for violation of the Act. ${ }^{37}$ Whilst the legislation provides a mechanism to ensure the compliance of political parties with the legislature, it does not stipulate a dispute resolution mechanism for political parties who have been aggrieved. The Post-Election Assessment Report outlines that if the Election Committee failed to resolve a complaint, an area of unfamiliarity is entered into, stating:

It is not clear whether the court system [would] entertain and exercise jurisdiction over grievances arising out of the election process. There are no precedents, and the electoral legislation and regulations themselves are unclear. ${ }^{38}$

In the example above regarding the Election Committee, the parties that did not meet the 'legal requirements' to

${ }^{36}$ Undang-Undang Republik Indonesia Nomor 2 Tahun 1999 Tentang Perubahan Atas [Laws of the Republic Indonesia Number 2 of 1999 On Political Parties] (Indonesia) art 17(1) [author's trans].

${ }^{37}$ Undang-Undang Republik Indonesia Nomor 2 Tahun 1999 Tentang Perubahan Atas [Laws of the Republic Indonesia Number 2 of 1999 On Political Parties] (Indonesia) art 17(2) [author's trans].

${ }^{38}$ Glenn Cowan, 'The 1999 Election and Post-Election Developments in Indonesia: A Post-Election Assessment Report'(Research Report, The National Democratic Institution, 28 November 1999) 10. participate in the General Election had no avenue to dispute this decision. It can be concluded therefore, that Law No. 2 of 1999 impedes upon the promotion of justice as the lack of appeal process results in denying equality before the law.

The notion of democracy, where the legislature is representative of the entire population, ${ }^{39}$ is infringed upon due to Law No. 3 of 1999 allowing for the appointment of members of the People's Consultative Assembly (MPR). The 1999 election was conducted under the reformed system in which the 700-member MPR was composed of 462 members of the legislature, 38 members of the military and 200 members appointed by the government, resulting in $34 \%$ of the MPR being unelected officials. ${ }^{40}$ Article 42 states that the members of the Armed Forces are not required to be elected via the General Election, but are rather to be appointed to their position. ${ }^{41}$ It is inherently undemocratic for the

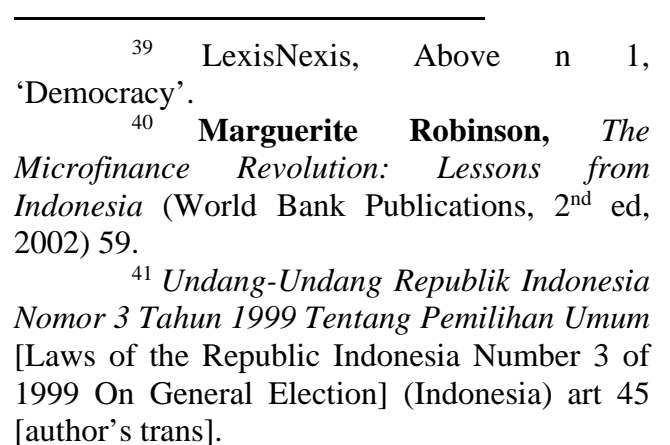


reservation of seat in the legislative branch, and the appointment of military personnel raises further implications as to what the role of the military is - a voice to lead the people, or to serve and protect them? Further, it is the role of the MPR to determine the President and Vice President of Indonesia. ${ }^{42}$ With the restraints on democracy as outlined above, the outcome of the determination of the president may be significantly different to that of the parliamentary election. For example, Magawati Soekarnoputri was not selected as President in 1999, whilst her party won the general election, 43 raising implications as depth of these democratic ideals in which the law attempts to achieve. Due to this mechanism of appointment allowed by Law No. 3 of 1999 the leadership of Indonesia is not representative of the people's choices, and therefore does not promote justice in its totality.

A legal system that adopts the notion of democracy will further the promotion of justice than one that does

42 Donald Horowitz, Constitutional Change and Democracy in Indonesia (Cambridge University Press, 2013) 109.

${ }^{43}$ Hosen, 'Indonesian Political Laws in Habibie Era: Between Political Struggle and Law Reform', above n 29. not. ${ }^{44}$ Whilst observing only the benefits derived from Law No. 2 of 1999 and Law No. 3 of 1999, some may argue that justice was achieved as Indonesia has its first 'free and fair' election. However, due to the vagueness of the introduced laws resulting in arbitrary decision-making, a lack of appeal process offending the principle of equality before the law, and the appointment of members of the legislature infringe upon the ideals of democracy, these reforms did not achieve the promotion of absolute justice.

\section{ANTI-CORRUPTION LAW REFORM}

Corruption has been a serious obstacle throughout Indonesia's history and, arguably, reducing corrupt practices within the governmental and judicial structure has been sluggish due to the culture of patronage within both politics and business. ${ }^{45}$ During B.J. Habibie's presidency in the years 19981999, two law reforms were introduced, Law 28 of 1999 on Corruption,

\footnotetext{
${ }^{44}$ Barry, above $n 7$.

${ }^{45}$ Helena Varkkey, 'Patronage politics as a driver of economic regionalisation: The Indonesian Oil Palm Sector and Transboundary Haze' (2012) 53(3) Asia Pacific Viewpoint 314, 315.
} 
Collusion and Nepotism and Law No. 31 of 1999 on the Eradication of Corruption, ${ }^{46}$ to ensure the eradication of corruption, the creation of an ethical government and to ensure the promotion of justice within Indonesian society. However, it can be argued that these laws fell short of the standard required to ensure the promotion of justice. This is evident through an examination of the mechanisms introduced to fight corruption that failed to be implemented uniformly, and the laws promoted arbitrary decisionmaking through the depth of discretion they permitted.

Law No. 28 of 1999 and Law No. 31 of 1999 do not result in the total promotion of justice as they violate the foundational elements of the term, particularly the requirement of equality before the law, as the mechanisms in which the laws created failed to apply to the Golkar Party. Law No. 28 of 1999 created an independent corruption body

\footnotetext{
${ }^{46}$ Undang-Undang Republik Indonesia Nomor 28 Tahun 1999 Tentang Penyelenggara Negara Yang Bersih Dan Korupsi, Kolusi Dan Nepotisme [Laws of the Republic Indonesia Number 28 of 1999 On Organizers of the Clean and Free From Corruption, Collusion and Nepotism] (Indonesia) [author's trans]; Undang-Undang Republik Indonesia Nomor 31 Tahun 1999 Tentang Pemberantas San Tindak Pidana Korupsi [Laws of the Republic Indonesia Number 31 of 1999 On Eradication of Corruption] (Indonesia) [author's trans].
}

called the KPKPN, which has the task of auditing the assets of State Functionaries. ${ }^{47}$ Law No. 31 of 1999 authorised the formation of the Corruption Eradication Commission (KPK), a body with superior investigative powers in matters relating to corruption. ${ }^{48}$ However the delay in the formation of these bodies ensures the obstruction of justice, as they were to be established one and two years after the commencement of the laws, respectfully. ${ }^{49}$ It can be argued that the laws were implemented to ensure that the Habibie government and the members of parliament did not have to report their assets to the KPKPN, nor be

${ }^{47}$ Undang-Undang Republik Indonesia Nomor 28 Tahun 1999 Tentang Penyelenggara Negara Yang Bersih Dan Korupsi, Kolusi Dan Nepotisme [Laws of the Republic Indonesia Number 28 of 1999 On Organizers of the Clean and Free From Corruption, Collusion and Nepotism] (Indonesia) art 10 [author's trans].

${ }^{48}$ Undang-Undang Republik Indonesia Nomor 31 Tahun 1999 Tentang Pemberantas San Tindak Pidana Korupsi [Laws of the Republic Indonesia Number 31 of 1999 On Eradication of Corruption] (Indonesia) art 43(1) [author's trans].

${ }^{49}$ Undang-Undang Republik Indonesia Nomor 28 Tahun 1999 Tentang Penyelenggara Negara Yang Bersih Dan Korupsi, Kolusi Dan Nepotisme [Laws of the Republic Indonesia Number 28 of 1999 On Organizers of the Clean and Free From Corruption, Collusion and Nepotism] (Indonesia) art 24 [author's trans]; Undang-Undang Republik Indonesia Nomor 31 Tahun 1999 Tentang Pemberantas San Tindak Pidana Korupsi [Laws of the Republic Indonesia Number 31 of 1999 On Eradication of Corruption] (Indonesia) art 43(1) [author's trans]. 
the target of KPK investigations. Damien Kingsbury states that corruption was not addressed during Habibie's reign as he was "himself a beneficiary of corruption and nepotism, while his party, Golkar, was able to function only as a result of its various and usually illegal money-gathering schemes". ${ }^{50}$ Neither Law No. 28 of 1999 nor Law No. 31 of 1999 resulted in the complete promotion of justice as the mechanisms in which the created resulted in the violation of equality before the law.

Additionally, through the failure to ensure the proportionate implementation of the laws throughout society, Law No. 28 of 1999 and Law No. 31 of 1999 breach the notion of equality before the law, and thus may not fulfil the promotion of complete justice. As explored above, the KPKPN and the KPK were granted the role of investigating cases of corruption, 51

${ }^{50}$ Damien Kingsbury, The Politics of Indonesia (Oxford University Press, $2^{\text {nd }}$ ed, 2002) 213.

${ }^{51}$ Undang-Undang Republik Indonesia Nomor 28 Tahun 1999 Tentang Penyelenggara Negara Yang Bersih Dan Korupsi, Kolusi Dan Nepotisme [Laws of the Republic Indonesia Number 28 of 1999 On Organizers of the Clean and Free From Corruption, Collusion and Nepotism] (Indonesia) art 17(2)(b) [author's trans]; Undang-Undang Republik Indonesia Nomor 31 Tahun 1999 Tentang Pemberantas San Tindak Pidana Korupsi [Laws of the Republic Indonesia Number 31 of 1999 On however prosecution and conviction was the role of the Attorney General and the "notoriously corrupt, poorlytrained, and poorly-paid judiciary”. ${ }^{52}$ Data from March 2000 shows that, despite these reforms, less than $20 \%$ of investigated corruption cases had been resolved. ${ }^{53} \mathrm{~A}$ report submitted to the United Nations for the $108^{\text {th }}$ Geneva Convention states:

Prosecutors are generally unwilling to investigate cases that may implicate members of the Government. The Attorney General continues to apply certain manipulated or incorrect interpretations of law to refuse prosecution. For instance, the Attorney General has asserted the principle of ne bis in idem (double jeopardy) [in cases where it is not applicable]. ${ }^{54}$

However, statistics from the 1998 Accountability Report show that, from May 1998 to June 1999, the number of corruption cases investigated

Eradication of Corruption] (Indonesia) art 43(2) [author's trans].

52 Dwight King, 'Corruption in Indonesia: A Curable Cancer?’ (2002) 53(2) Journal of International Affairs 603, 611.

${ }^{53}$ Timothy Lindsey (ed), Indonesia, Law and Society (The Federation Press, 2nd ed, 2008) 131.

54 The International Federation for Human Rights, Submission to United Nations Human Rights Committee, Parallel Report to the Initial Report of Indonesia on the International Covenant on Civil and Political Rights, 10 July 2013, 5. 
increased by 321\% compared to that during Soeharto's presidency. ${ }^{55}$ What is lacking from this report is that a large majority of the cases brought to the courts involve only minor incidents, as neither the Chief Prosecutor nor the Chief of Police were prepared to prosecute prominent governmental figures. 56 Indeed, both the Chief Prosecutor and the Chief of Police were seen as lacking integrity themselves, with the Chief Prosecutor later being forced to step down, but avoiding prosecution, due to his own corruption scandal. ${ }^{57}$ This lack of equality in the implementation of Law No. 28 of 1999 and Law No. 31 of 1999 to prominent figures ensures that the promotion of justice is obstructed.

Further, Law No. 28 of 1999 and Law No. 31 of 1999 allow for arbitrary decision-making through the depth of discretion they permit, resulting in a failure to promote justice in its entirety. Whilst both reforms introduced numerous repressive measures to reduce the occurrence corruption, 58 the

\footnotetext{
${ }^{55}$ Lindsey, above n 51, 14.

${ }^{56}$ Ibid.

57 Ibid.

58 See Undang-Undang Republik Indonesia Nomor 31 Tahun 1999 Tentang Pemberantas San Tindak Pidana Korupsi [Laws of the Republic Indonesia Number 31 of 1999 On Eradication of Corruption] (Indonesia) art 2-
}

theoretical foundation of these is, arguably, incorrect. The basis of these reforms is that imprisonment plays the foremost role in reducing the occurrence of corruption. ${ }^{59}$ Higher penalties may decrease the number of those who participate in corruption, due to their deterrent effect, ${ }^{60}$ however they may also lead to an increase in bribes towards the judiciary for those who are not primarily deterred. Data from the Political \& Economic Risk Consultancy show that corruption following the introduction of Law No. 28 of 1999 and Law No. 31 of 1999 increased, with grades of 8.67 in 1997, 8.96 in 1998 and 9.91 in 1999. ${ }^{61}$ The grades are scaled from 0 to 10 , with 0 representing no corruption, ${ }^{62}$ emphasizing the failure of these repressive measures. Further, there seems to be disparity between the

20 [author's trans]; Undang-Undang Republik Indonesia Nomor 28 Tahun 1999 Tentang Penyelenggara Negara Yang Bersih Dan Korupsi, Kolusi Dan Nepotisme [Laws of the Republic Indonesia Number 28 of 1999 On Organizers of the Clean and Free From Corruption, Collusion and Nepotism] (Indonesia) art 21-22 [author's trans].

${ }^{59}$ Donald Ritchie, 'Sentencing Matters: Does Imprisonment Deter? A Review of the Evidence' (Research Report, Victorian Sentencing Advisory Council, April 2011) 2.

${ }^{60}$ Ibid.

61 Theresa Thompson and Anwar Shah, Transparency International's Corruption Perceptions Index: Whose Perceptions Are They Anyway? (Research Report, The World Bank, March 2005) 10.

${ }^{62}$ Ibid. 
penalties mandated in the law and the penalties that are imposed, evincing the lack of connection between limiting the judge's discretion and an increase in penalties. ${ }^{63}$ In a context with corruption flourishing, this ‘discretion’ can be used as a means to negotiate. For example, whilst Law No 31 of 1999 mandates a 4-year minimum sentence, 64 the Criminal Code implements a 1-year imprisonment as a minimum sentence for the same crime. ${ }^{65}$ With the Attorney General, police and judges able to choose which is 'more applicable' to the facts, there is a perception that penalties will be applied selectively or arbitrarily. ${ }^{66}$ It can therefore be concluded that Law No. 28 of 1999 and Law No. 31 of 1999 does not promote justice in its totality due to the allowance for arbitrary decision-making through the depth of discretion permitted.

\footnotetext{
${ }^{63}$ Hosen, Reform of Indonesian Law in the Post-Soeharto era (1998-1999), above n 29, 11.

${ }^{64}$ Undang-Undang Republik Indonesia Nomor 31 Tahun 1999 Tentang Pemberantas San Tindak Pidana Korupsi [Laws of the Republic Indonesia Number 31 of 1999 On Eradication of Corruption] (Indonesia) art 2 [author's trans].

65 Kode Kriminal [Criminal Code] (Indonesia) art 5 [author's trans].

${ }^{66}$ Hosen, Reform of Indonesian Law in the Post-Soeharto era (1998-1999), above n 29, 11.
}

It can be concluded that Law 28 of 1999 on Corruption, Collusion and Nepotism and Law No. 31 of 1999 on the Eradication of Corruption do not ensure the promotion of justice within Indonesian society. The ineffectiveness of these reforms is evident as the level of corruption increased throughout Indonesia. Further, these laws fell short of the standard required to promote the total achievement of justice as they violated the notions of equality before the law and arbitrary decision-making. This is evident through the examination of their corruption-fighting measures, which were inapplicable to the Golkar party, a failure to implement the law uniformly and allowing for unrestricted discretion.

\section{HUMAN RIGHTS LAW REFORM}

With the introduction of Law No. 39 of 1999 on Human Rights, Indonesia aimed to establish a legal foundation for the protection of human rights and punish the perpetrators of past violations. However, whilst this law has led to significant improvements in the area of establishing a legal foundation for the future protection of human rights, the implementation of the law has lacked in practicality. 
Observing the legislation in isolation, it promotes equality before the law and ensures the absence of arbitrariness. However, issues such as the ineffectiveness of procedures and the militaristic legal culture raises questions as to how effectively Law No. 39 of 1999 can promote justice.

The content of Law No. 39 of 1999 promotes the achievement of justice due to the standard of human rights protection it confers, thus ensuring equality before the law and the absence of arbitrariness. The content of the law is deemed to be within the minimum standard required by the International Commission of Jurists (ICJ) and that required of international human rights law. ${ }^{67}$ Fundamentally, the law expanded the powers of the National Commission of Human Rights (Komnas HAM) in its role in the promotion and protection of human rights throughout Indonesia. ${ }^{68}$ The newly conferred functions are "to study, research, disseminate, monitor and mediate human rights issues”, ${ }^{69}$ and therefore "improve the protection and

${ }^{67}$ Ibid, 205.

${ }^{68}$ Lindsey, above n 50, 461.

69 Undang-Undang Republik Indonesia Nomor 39 Tahun 1999 Tentang Hak Asasi Manusia [Laws of the Republic Indonesia Number 39 of 1999 On Human Rights] (Indonesia) art 98 [author's trans]. the upholding of human rights in the interests of ... the Indonesian people as a whole", ${ }^{70}$ To ensure the independence of the body, article 98 ensures the funding of Komnas HAM is via the State budget, ensuring accountability to the People's Representative Council (DPR) rather than the Cabinet, as was previously the case. ${ }^{71}$ At an international level, Komnas HAM has quickly fostered a meaningful reputation as an impartial, outspoken, and conscientious human rights body, "often directly criticizing government policies, actions by the police and military, and highlighting human rights anomalies”, ${ }^{72}$ From the creation of this national human rights body, praised at an international level, it can be stated that the content of Law No. 39 of 1999 creates an institution that aims to achieve 'justice', through the promotion of equality and the abstinence of arbitrariness.

Whilst Law No. 39 of 1999 has led to a significant improvement the substance of the law, ineffective procedures have resulted in an inability to prosecute human rights violators,

\footnotetext{
${ }^{70}$ Ibid, art 75.

${ }^{71}$ Lindsey, above n 50, 461.

72 Philip Eldrige, 'Human Rights in Post-Suharto Indonesia’ (2001) 9(1) The Brown Journal of World Affairs 127, 130.
} 
raising implications as to whether the requirement of the due process of the law is satisfied. Whilst progress has been made, cases of human rights abuses such as arbitrary detentions, torture and other forms of mistreatment continue to be reported. ${ }^{73}$ According to many commentators, this is due to the structural issues that demand substantial improvements. ${ }^{74}$ The criminal judicial process in Indonesia is divided into four phases - inquiry, investigation, prosecution and court examination. ${ }^{75}$ Whilst Komnas HAM has the ability to inquire, Enny Soeprapto states that the body should have a larger role in the investigation stage "as there is not enough trust in the official organs”. ${ }^{76}$ In relation to the prosecution stage, Act No. 39 of 1999 does not outline the process that the judiciary should follow, as well as lacking clarification as to which court has authority in these

\footnotetext{
73 Hao Duy Phan, A Selective Approach to Establishing a Human Rights Mechanism in Southeast Asia: The Case for a Southeast Asian Court of Human Rights (Brill Academic Publishing, $1^{\text {st }}$ ed, 2012) 49.

${ }^{74}$ Ibid.

75 Theodor Rathgeber, 'Strengthening Human Rights in Indonesia' (speech delivered at the German Forum of Human Rights, Geneva's Friedrich Ebert Stifttung Office, 5 April 2005)

$<$ http://www.watchindonesia.org/Strengthening HumanRightsIndonesia.pdf $>$

${ }^{76}$ Ibid.
}

matters. ${ }^{77}$ As a result, for five years from the implementation of the Act, not a single case of alleged human rights violation was judicially processed. ${ }^{78}$ These procedural barriers have resulted in the absence in the due process of the law, and therefore as a matter of practicality, Law No. 39 of 1999 does promote justice in its totality.

A further barrier to the achievement of justice and the enforcement of Law No. 39 of 1999 can be attributed to the severity of the change to the substance of the law, which due to the legal culture of Indonesia diminished the notion of equality before the law. Monika Schlicher, a spokesperson for the nongovernmental organisation Watch Indonesia, stated, "the human rights situation in Indonesia has not improved significantly” due to the strong culture of militarism and the slow reform of police attitudes. ${ }^{79}$ This is evident through the examination of the Semanggii tragedy that occurred months after the introduction of Law No. 39 of 1999, where the Indonesian Military committed a grave violation of human rights. Students participating in a

$$
\begin{aligned}
& { }^{77} \text { Ibid. } \\
& { }^{78} \text { Ibid. } \\
& { }^{79} \text { Ibid. }
\end{aligned}
$$


peaceful protest were fired on by the military, killing numerous students and hapless bystanders. ${ }^{80}$ Komnas HAM issued numerous summonses to those who ordered the attack, however they refused to answer due to the belief that their actions were lawful. ${ }^{81}$ The legal culture of militarism hinders the applicability and enforcement of Law No. 39 of 1999. Due to this barrier the administration of justice is significantly problematic due to the lack of equality before the law.

In summary, the introduction of Law No. 39 of 1999 has improved the legal foundation to protect human rights by granting Komnas HAM a greater role in their protection. This, in isolation, promotes equality before the law and ensures the absence of arbitrariness. However, the implementation of Law No. 39 of 1999 faces numerous barriers, such as insufficient procedures and the militaristic culture of Indonesia, which in tern, result in the absence of due process and equality before the law.

80 Katinka van Heeren, Contemporary Indonesian Film: Spirits of Reform and Ghosts from the Past (Brill Academic Publishing, $1^{\text {st }}$ ed, 2013) 125.

81 Hikmahanto Juwana, 'Assessing Indonesia's Human Rights Practice In The PostSoeharto Era: 1998-2003' (2003) 7 Singapore Journal of International and Comparative Law 644, 667.
Therefore, whilst Law No. 39 of 1999 has assisted in the achievement of justice, it cannot be deemed to fulfill the aim of achieving total justice.

\section{CONCLUSION}

The aim of law reform is the promotion of justice, however without meeting the requirements of equality before the law, enforcing the ideal of democracy and ensuring an absence of arbitrariness, meeting this standard is unrealistic. The reforms of 1999 - No. 2 of 1999 on Political Parties, No. 3 of 1999 on General Elections, No. 28 of 1999 on Corruption, Collusion and Nepotism, No. 31 of 1999 on the Eradication of Corruption and No. 39 of 1999 on Human Rights - significantly contributed to the absence of the promotion of justice in its totality. Following the analysis of these laws, it is evident that the need for further reform is essential: the achievement of justice should be the priority.

\section{REFERENCE}

\section{ARTICLES/BOOKS/REPORTS}

Achmad Ali, 'Law and Development in Changing Indonesia' (Research Report, No 8, Institute of Developing Economies, 12 March 2001) 
Antlöv, Hans and Sven Cederroth, Elections in Indonesia: The New Order and Beyond (RoutledgeCurzon, 2004)

Aristotle, Nicomachean Ethics (Hackett Publishing Company, 2nd ed, 1999)

Aristotle, Politics (University of Chicago Press, 2nd ed, 2013)

Barry, Brian, Theories of Justice (University of California Press, 1991)

Bodenheimer, Edgar, Jurisprudence: The Philosophy and Method of the Law (Harvard University Press, 2nd ed, 1967)

Butt, Peter and David Hamer (eds), LexisNexis Concise Australian Legal Dictionary (LexisNexis, $4^{\text {th }}$ ed, 2011)

Byrne, David 'Equality Before the Law' (1970) 2 Dublin University Law Review 40

Cowan, Glenn, 'The 1999 Election and Post-Election Developments in Indonesia: A Post-Election Assessment Report' (Research Report, The National Democratic Institution, 28 November 1999)

Eldrige, Philip, 'Human Rights in PostSuharto Indonesia' (2001) 9(1) The Brown Journal of World Affairs 127

Habermas, Jürgen, Legitimation Crisis (Beacon Press, 1975)

Heeren, Katinka van, Contemporary Indonesian Film: Spirits of
Reform and Ghosts from the Past (Brill Academic Publishing, 1st ed, 2013)

Hill, Gerald and Kathleen Hill, The People's Law Dictionary (MFJ Books, 2002)

Hillman, Ben, 'Electoral Governance and Democratic Consolidation in Indonesia' (2011) 39(3) The Indonesian Quarterly 301

Horowitz, Donald, Constitutional Change and Democracy in Indonesia (Cambridge University Press, 2013)

Hosen, Nadirsyah 'Indonesian Political Laws in Habibie Era: Between Political Struggle and Law Reform' (2003) 72 Nordic Journal of International Law 483

Juwana, Hikmahanto, 'Assessing Indonesia's Human Rights Practice In the Post-Soeharto Era: 1998-2003' (2003) 7 Singapore Journal of International and Comparative Law 644

King, Dwight, 'Corruption in Indonesia: A Curable Cancer?’ (2002) 53(2) Journal of International Affairs 603

Kingsbury, Damien, The Politics of Indonesia (Oxford University Press, 2nd ed, 2002)

Kumm, Mattias 'The Legitimacy of International Law: A Constitutionalist Framework of Analysis’ (2004) 15(5) European Journal of International Law 907 
Lindsey, Timothy (ed), Indonesia, Law and Society (The Federation Press, 2nd ed, 2008)

McLeod, Ross, 'Soeharto’s Indonesia: A Better Class of Corruption' (2000) 7(2) Agenda: A Journal of Policy Analysis and Reform 99

Mill, John Stuart, Utilitarianism (Hackett Publishing Company, 2nd ed, 2002)

Phan, Hao Duy, A Selective Approach to Establishing a Human Rights Mechanism in Southeast Asia: The Case for a Southeast Asian Court of Human Rights (Brill Academic Publishing, 1st ed, 2012)

Plato, Laws (Dover Publications, 2006)

Robinson, Marguerite, The Microfinance Revolution: Lessons from Indonesia (World Bank Publications, 2nd ed, 2002)

Ritchie, Donald, 'Sentencing Matters: Does Imprisonment Deter? A Review of the Evidence' (Research Report, Victorian Sentencing Advisory Council, April 2011)

Ryters, Loren, 'Pemuda Pancasila: The Last Loyalist Free Men of Suharto's Order?' (1998) 66 Indonesia 44

Saunders, Joseph, Academic Freedom in Indonesia: Dismantling Soeharto-era Barriers (Human Rights Watch, 1998)
Stromseth, Jane, 'Pursuing Accountability for Atrocities After Conflict: What Impact on Building the Rule of Law?' (2007) 38 Georgetown Journal of International Law 251

Suryadinata, Leo, Elections and Politics in Indonesia (Institute of Southeast Asian Studies, 2002)

Suryadinata, Leo, 'A Year of Upheaval and Uncertainty: The Fall of Soeharto and Rise of Habibie' [1999] Southeast Asian Affairs 111

Thompson, Theresa and Anwar Shah, Transparency International's Corruption Perceptions Index: Whose Perceptions Are They Anyway? (Research Report, The World Bank, March 2005)

Varkkey, Donald, 'Patronage politics as a driver of economic regionalisation: The Indonesian Oil Palm Sector and Transboundary Haze' (2012) 53(3) Asia Pacific Viewpoint 314

\section{LEGISLATION}

Kode Kriminal [Criminal Code] (Indonesia) [author's trans]

Undang-Undang Republik Indonesia Nomor 2 Tahun 1999 Tentang Perubahan Atas [Laws of the Republic Indonesia Number 2 of 1999 On Political Parties] (Indonesia) [author's trans]

Undang-Undang Republik Indonesia Nomor 3 Tahun 1999 Tentang Pemilihan Umum [Laws of the 
Republic Indonesia Number 3 of 1999 On General Election] (Indonesia) [author's trans]

Undang-Undang Republik Indonesia Nomor 28 Tahun 1999 Tentang Penyelenggara Negara Yang Bersih Dan Korupsi, Kolusi Dan Nepotisme [Laws of the Republic Indonesia Number 28 of 1999 On Organizers of the Clean and Free From Corruption, Collusion and Nepotism] (Indonesia)

Undang-Undang Republik Indonesia Nomor 31 Tahun 1999 Tentang Pemberantas San Tindak Pidana Korupsi [Laws of the Republic Indonesia Number 31 of 1999 On Eradication of Corruption] (Indonesia)

\section{Undang-Undang Republik Indonesia} Nomor 39 Tahun 1999 Tentang Hak Asasi Manusia [Laws of the Republic Indonesia Number 39 of 1999 On Human Rights] (Indonesia) [author's trans]

\section{OTHERS}

Baron, Greg, ' Democracy in Indonesia' The Monthly (online) July 2009 $<$ https://www.themonthly.com.a u/issue/2009/july/1360559640/g reg-barton/comment>

Hosen, Nadirsyah, Reform of Indonesian Law in the PostSoeharto era (1998-1999) (PhD Thesis, The University of Wollongong, 2004)
International Federation for Human Rights, Submission to United Nations Human Rights Committee, Parallel Report to the Initial Report of Indonesia on the International Covenant on Civil and Political Rights, 10 July 2013

Kirby, Chief Justice Michael 'Law Reform and Class Actions' (Speech delivered at the Australian Society of Senior Executives, Sydney, 31 July 1979)

$<$ http://www.michaelkirby.com. au/images/stories/speeches/1970 s/vol4/1979/112-

Aus_Society_of_Senior_Executi ves_-

_Law_Reform_and_Class_Actio ns.pdf $>$

LexisNexis, Encyclopaedic Australian Legal Dictionary (at 10 February 2015)

MacIntyre, Andrew, 'Institutions and the Political Economy of Corruption in Developing Countries' (Paper presented at Workshop on Corruption, Stanford University, 31 February 2003)

Rathgeber, Theodor 'Strengthening Human Rights in Indonesia' (speech delivered at the German Forum of Human Rights, Geneva's Friedrich Ebert Stifttung Office, 5 April 2005) $<$ http://www.watchindonesia.org /StrengtheningHumanRightsInd onesia.pdf $>$ 